\title{
Spatial Relationships in Sympatric Populations of the Rodents: Clethrionomys glareolus, Microtus agrestis and Apodemus agrarius ${ }^{1}$
}

\author{
Henryka CHEŁKOWSKA, Wiera WALKOWA \& Krystyna ADAMCZYK
}

\begin{abstract}
Chełkowska H., Walkowa W. \& Adamczyk K., 1985: Spatial relationships in sympatric populations of the rodents: Clethrionomys glareolus, Microtus agrestis and Apodemus agrarius. Acta theriol., 30, 2: 51-78 [With 7 Tables \& 10 Figs.]

Spatial distribution and interactions were analysed for three cooccurring populations of the rodents Clethrionomys glareolus (Schreber, 1780), Microtus agrestis (Linnaeus, 1761) and Apodemus agrarius (Pallas, 1771). The study was conducted in three 1-ha plots located in forests of southern Poland, in an industrial region (Silesia). Rodents were captured by the CMR method from October 1977 to October 1981. The study areas differed in the degradation of plant communities and the degree of industrial pollution. It has been found that C. glareolus showed a higher degree of aggregation, less frequently changed the points of capture, and was most permanently attracted to them, as compared with the other species. All the rodent species tended to avoid one another at trapping points, especially $C$. glareolus and $M$. agrestis. There were differences in the values of various indices among particular plots, which can be related to the degree of plant cover degradation.

Department of Vertebrate Ecology, Institute of Ecology P. A. Sci. Dziekanów, 05-092 Łomianki, Poland]
\end{abstract}

\section{INTRODUCTION}

Small rodents living in mixed forests usually form multispecies communities. They have relatively similar food and habitat requirements. The distribution of individual species was analysed by many authors (Turček, 1960; Koplin \& Hoffman, 1968; Chełkowska, 1969; Flint, 1977; Dienske, 1979; Kovalevskij \& Korenberg, 1980; Bashenina, 1981; Andrzejewski \& Simonides, 1982, and others), but so far it is not clear how individual species occupy the habitat when they co-occur, and how they interact.

The purpose of this paper is to analyse differences in the distribution of co-occurring populations of C. glareolus (Schreber, 1780), M. agrestis (Linnaeus, 1761) and $A$. agrarius (Pallas, 1771), to find whether or not they interact, and to determine the effect of habitat on their spatial structure.

${ }^{1}$ Praca wykonana w ramach problemu 10.2 koordynowanego przez Instytut Podstaw Inżynierii Srodowiska PAN. 


\section{STUDY AREAS}

The study was carried out in southern Poland, in one of the most industrialized regions, called Upper Silesia (mostly in the Rybnik Coal Region, near Knurów), Almost half of this area is covered by forests, of which $80 \%$ are represented by Calamagrostio villosae-Pinetum Stasz. 1958 and Tilio-Carpinetum Tracz. 1962 (Celiński et al., 1982).

Three 1-ha study plots were established: (1) Plot A - at Knurów near a coke plant and a Light-Crushed Stone Plant (forest Aniolki). This was the most polluted and degraded of all the study habitats, covered by a transformed form of Tilio-Carpinetum Tracz. 1962 with Carex brizoides L., Rubus caesius L. and Pteridium aquilinum L., also by Pino-Quercetum (Kozł., 1925) Mat. et Pol. 1955, and Calamagrostio villosae-Pinetum Staszk, 1958. This area was heavily submerged because of earth subsidences.

(2) Plot S - at Szczygłowice, at a distance of about $10 \mathrm{~km}$ from plot $\mathrm{A}$, close to a pit-coal mine, in Tilio-Carpinetum with Carex brizoides and Pteridium aquilinum. This was a fertile, moist site with no heavily submerged areas like those in plot $\mathrm{A}$.

(3) Plot P - at Jankowice near Pszczyna, about $60 \mathrm{~km}$ distant from the other plots, in a large forest complex. This plot was covered by Tilio-Carpinetum with Carex brizoides and Pteridium aquilinum, and by Calamagrostio villosae-Pinetum. This was the least polluted and least degenerated habitat.

The degradation of plant communities on the study plots was estimated by Dr. S. Wika and Dr. S. Cabała using a 5-degree scale of Celiński and Wika (1980). This scale is based on changes in species composition, such as disappearance of characteristic plant species and appearance of non-typical, ruderal forms, and also on dying trees, leaf fall, absence of seeds, etc. Wika and Cabala also prepared a detailed botanical characteristic of the study plots. On this basis, several indices characterizing plant cover of the study plots were calculated. Also the coverage of earth surface by fallen trees and dry branches was estimated. The data on industrial dust fall were taken from Foik (1978) and Warteresiewicz (1979).

A comparison of these data for the three plots (Table 1) shows that plot A represented most transformed habitat. This is indicated by the highest values of 1) amount of industrial dust fall, 2) degree of the transformation of plant communities 3) number of plant species, 4) percentage cover with herbaceous plants, and 5) percentage cover with dead branches, fallen trees, and trunks.

\section{MATERIAL AND METHOD}

In 1977-1981, live-traps baited with oats were used to capture rodents. They were set in a $10-\mathrm{m}$ greed (10 rows with 10 trapping points, each). Distances between rows and between trapping points were $10 \mathrm{~m}$. There were two traps at each point. In plots $A$ and $S$, the study was continued for four years (from October 1977 to October 1981) and in plot P for 3.5 years (from July 1978 to October 1981). Each year there were four series of trapping (in May July September, and October). Each series extended for five days, and traps were checked twice a day (in the morning and in the evening), that is, traps were examined 10 times per series. The captured animals were individually marked by clipping their toe tips. Notes were taken of the species, trapping point number, 
sex, body weight, and animal number if recaptured. The animals were released in the place of capture (the CMR method). Over the entire study period there were 17 trapping series on plots $\mathrm{A}$ and $\mathrm{S}$, and 15 series on plot $\mathrm{P}$.

In addition, the materials collected by snap-trapping in 1977 and 1982 were used to analyse differences in the autumn peak numbers between plots $\mathrm{A}$ and $\mathrm{S}$. Snap traps were set on the same plots. In 1982, their number and distribution was identical with those of live-traps in preceding years. In 1977, however, snap traps were set in two parallel lines $20 \mathrm{~m}$ apart. The distance between trapping points on each line was $10 \mathrm{~m}$, and two traps were at each point.

On the study plots seven rodent species were captured: Clethrionomys glareolus, Microtus agrestis, Apodemus agrarius, Apodemus flavicollis (Melchior, 1834), Micromys minutus (Pallas, 1778), Muscardinus avelanarius (Linnaeus, 1758), and Mus musculus Linnaeus, 1758. The last three species were represented by

Table 1

Characteristics of the three study plots (after Walkowa. Adamczyk \& Chelkowska, 1982).

\begin{tabular}{lccc}
\hline \multicolumn{1}{c}{ Index } & \multicolumn{3}{c}{ Study plots } \\
\cline { 2 - 4 } \cline { 3 - 4 } & $\mathrm{A}$ & $\mathrm{S}$ & $\mathrm{P}$ \\
\hline $\begin{array}{l}\text { Dust fall in t/km²/year } \\
\text { Degree of plant community degradation }\end{array}$ & 450 & 165 & 130 \\
$\begin{array}{l}\text { Mean number of all plant } \\
\text { species per trapping point }\end{array}$ & IV & III & II \\
$\begin{array}{l}\text { Mean number of plant species in } \\
\text { herb layer per trapping point }\end{array}$ & 12.8 & 8.4 & 10.6 \\
$\begin{array}{l}\text { Sum percent herb layer coverage } 2 \\
\text { per trapping point }\end{array}$ & 10.2 & 5.4 & 8.9 \\
$\begin{array}{l}\text { Percent undergrowth coverage } \\
\text { per trapping point }\end{array}$ & 157 & 101 & 96 \\
$\begin{array}{l}\text { Percent coverage with fallen } \\
\text { trees and dry branches }\end{array}$ & 18.1 & 49.0 & 27.2 \\
\hline
\end{tabular}

1 After Foik (1978) and Warteresiewicz (1979).

2 Percentage cover by individual plant species were summed.

only a few individuals, thus they were not analysed. Spatial distribution was analysed for only three species, C. glareolus, M. agrestis, and A. agrarius, because they were most abundant. Besides rodents, also insectivores (Sorex sp.) were occasionally captured, which usually died in traps.

\section{NUMBERS OF RODENTS}

During three years (1977-1979), the total number of rodents in the period of peak numbers (in September) was highest on plot A. In the two following years, their number was lower on this plot than on the other plots, especially in 1980 (Fig. 1). In 1982, the total number of rocents on plot $\mathrm{A}$ in the period of autumn peak was higher again, as conpared with that on plot S (on plot P, the study was not continued). This, during a six-year study period, the total number of rodents on 
plot A was higher than on the other plots in four years. This shows; that generally the number of rodents was higher in this area.

Also the amplitude of fluctuation of the total number of rodents from spring to autumn was generally higher on plot A as compared with that on other plots (Table 2).

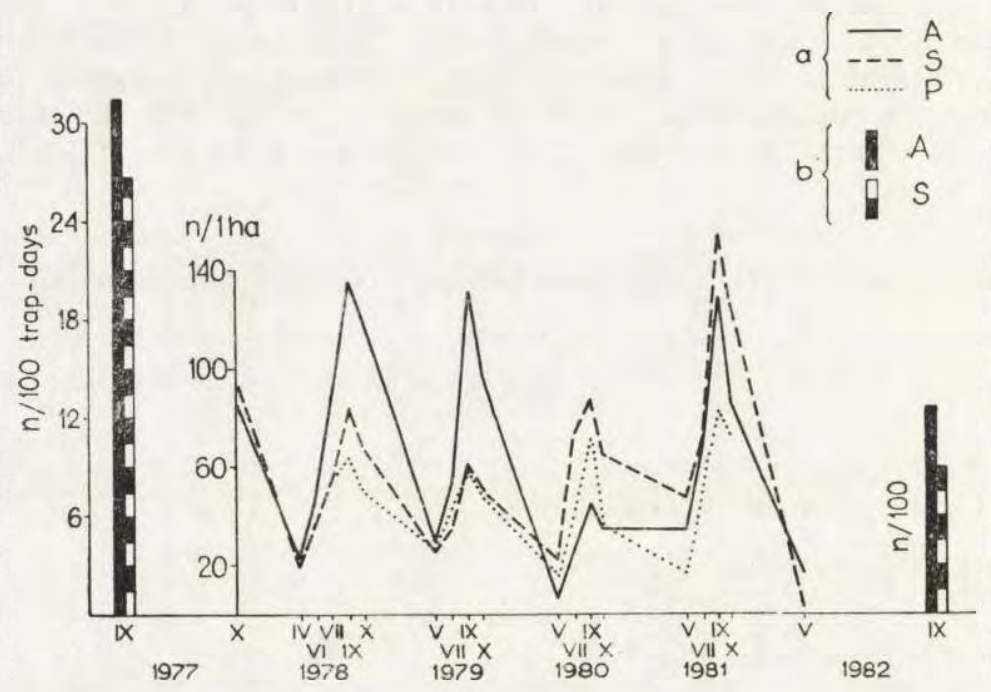

Fig. 1. Total numbers ( $\mathrm{n}$ ) of rodents on the study plots (A, S, P). (a) CMR method, (b) snap trapping method.

Table 2

Multiples of an increase in the total number of rodents from spring to the autumn peak.

\begin{tabular}{lrrr}
\hline \multirow{2}{*}{ Year } & \multicolumn{3}{c}{ Study plots } \\
\cline { 2 - 4 } & A & S & P \\
\hline 1977 & 3.9 & 1.2 & - \\
1978 & 4.5 & 3.2 & - \\
1979 & 4.5 & 2.4 & 2.1 \\
1980 & 6.6 & 4.4 & 4.7 \\
1981 & 3.8 & 3.3 & 5.4 \\
\hline
\end{tabular}

On two plots (S and P), C. glareolus was the dominant species for most of the study period (Fig. 2). On plot A, its numbers were lower, and the community was predominated by $M$. agrestis or $A$. agrarizs. A. flavicollis was relatively scarce on all the plots. 


\section{HOME RANGE SIZE}

To assess spatial relationships among three most abundant species, first the mean size of their home ranges was estimated. It has been assumed after Wierzbowska (1972) that the number of trapping points
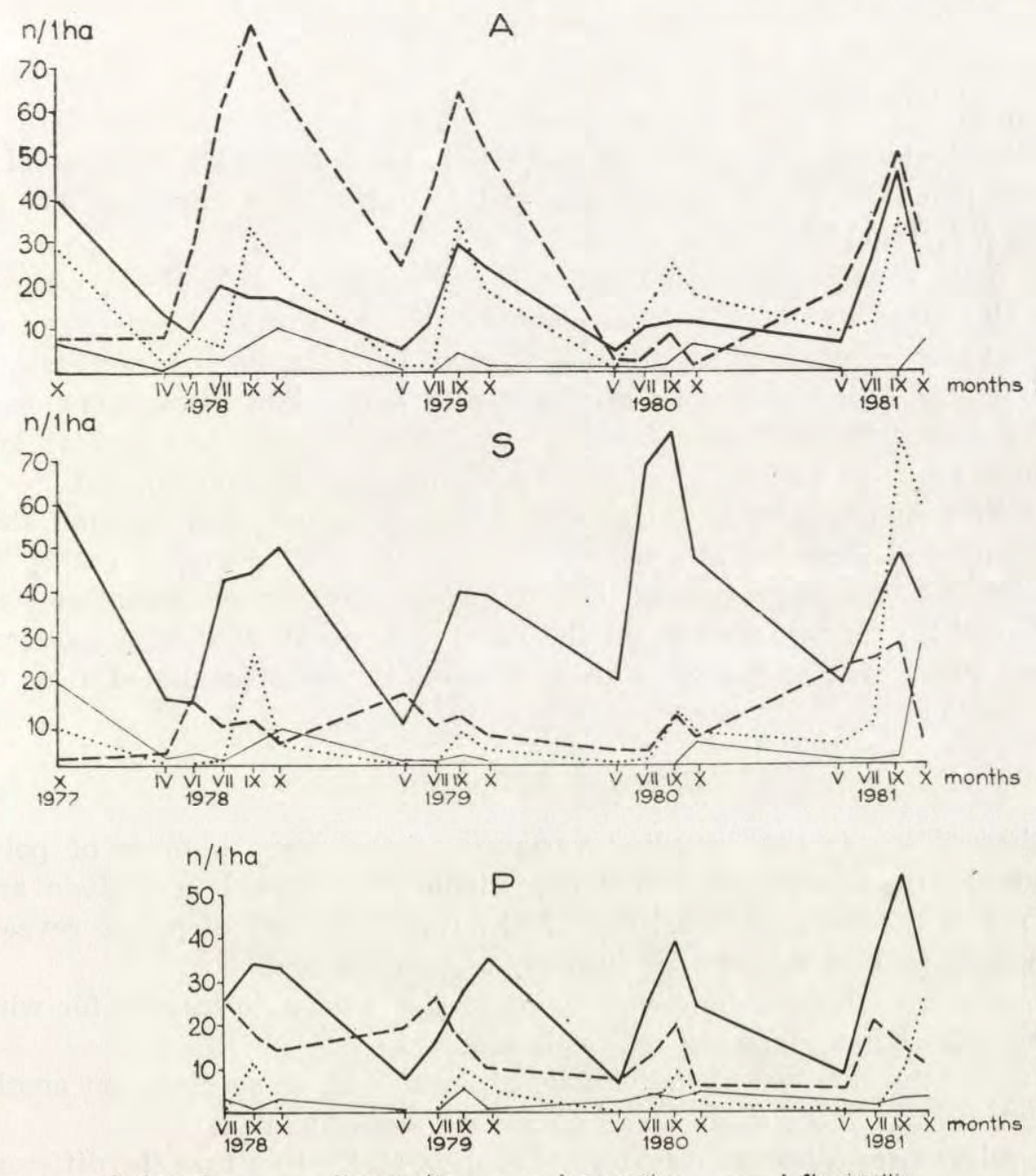

Calareolus --Magrestis _....... Aagrarius - A flavicollis

Fig. 2. Numbers of individuals ( $n$ ) in populations of different rodents (the CMR method) on the plots A, S, and P.

within the area searched by an individual rodent is a measure of its home range size. This method can be used to estimate a mean home range size of individuals captured at least two times. Home range size 
is calculated from a relationship between the mean number of points revealed by a rodent in a fixed number of captures $(k)$, on the one hand, and the number of these captures and the home range size $(r)$ on the other, as expressed by the formula

$$
E\left(X_{k, r}\right)=r\left[\left(1-\frac{r-1}{r}\right)^{k}\right]
$$

where $E\left(X_{k, r}\right)$ is the mean number of trapping points visited by an individual in $k$ successive captures, $k$ is the number of captures of an individual, $X_{k, r}$ is the number of points visited in $k$ captures, and $r$ is the individual home range size.

This equation is solved for $r$ by substituting $E\left(X_{k}, r\right)=\bar{x}$, where $\bar{x}$ is the mean number of points revealed by the captured rodents of one species in a series of captures. Individual home range size can easily be estimated using tables in Wierzbowska (1972). The mean home range size has been estimated for a group of individuals captured at least three times in a series of captures over a four-year study period.

The significance of differences in home range sizes for the three species and plots has also been calculated after Wierzbowska (1972). The difference between two arithmetic mean numbers of points revealed $\left(\bar{X}_{k 1}-\bar{X}_{k 11}\right)$ for two species on the same plot, or for the same species on two plots, was compared with a theoretical value calculated from the formula

$$
\lambda=1.96 \sqrt{S^{2}{ }_{k, r 1} \mid N_{k}, \mathrm{I}+S^{2} k_{,}, r 2} \overline{N_{k, \text { II }}}
$$

where $S^{2}{ }_{k, r 1}$ is the sampling variance of the mean number of points' revealed in $k$ captures $(k=3)$ by rodents of species I in a given area, $S_{k, r_{2}}$ is the sampling variance of the mean number of points revealed by species II on this plot, or species I on another plot,

$N_{k, \mathrm{I}}$ is the number of individuals of species I on a given plot, for which the mean home range size was estimated,

$N_{k}$, II is the number of individuals of species II, or species I on another plot, for which the mean home range size was estimated.

It follows from inequality $\left(\bar{X}_{k, \mathrm{I}}-\bar{X}_{k, \text { II }}\right)>\lambda$ at $P=0.05$ that the difference between the two compared home range sizes is statistically significant ( $r_{1}$ significantly differs from $r_{2}$ ).

In this way individual home ranges of particular species have been compared on each plot separately (Fig. 3). There were significant differences in home range size between $C$. glareolus and $M$. agrestis on two plots: on plot A, the home range of C. glareolus was larger than that of $M$. agrestis, and on plot S. M. agrestis established larger home 
ranges than $C$. glareolus. No significant differences in home range size between these two species were found on plot P. Generally, the home ranges of these species were smaller than those of $A$. agrarius. No significant differences occurred in the home range size of $A$. agrarius between different plots (Fig. 3).

For each species, home ranges of males were larger than those of females, though not all differences were statistically significant (Fig. 4). The only exception was $M$. agrestis on plot $\mathrm{S}$, where the home ranges of males were smaller than those of females but the difference was not statistically significant. Also the literature data show that males of these species have larger home ranges than females (Andrzejewski \& Wierzbowska, 1970; Myllymäki, 1977 b; Bashenina, 1981; Mazurkiewicz, 1981).

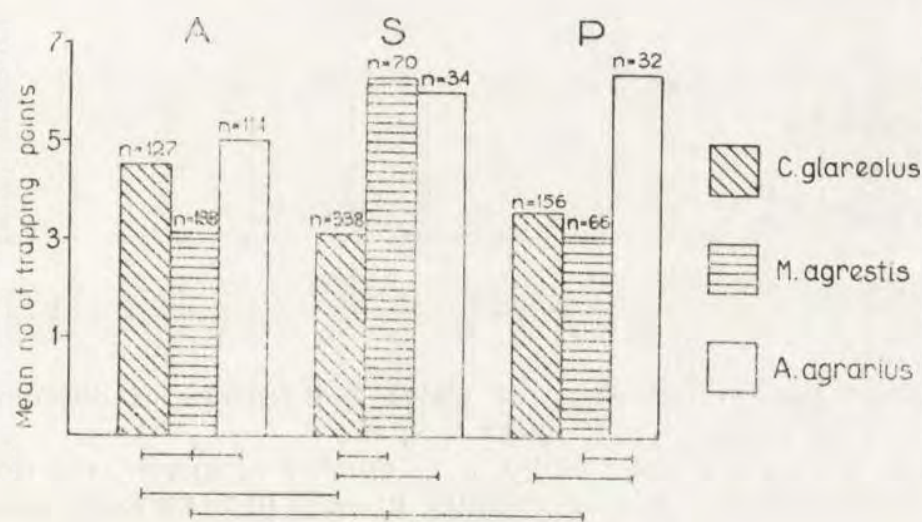

Fig. 3. Mean size of home ranges as measured by the number of trapping points visited (after Wierzbowska, 1972) for different species on various plots.

Horizontal lines under the diagram join significanty different $(P<0.05)$ home range sizes, $\mathrm{n}-$ number of individuals.

A seasonal variability in home range sizes was analysed for two periods: a spring-summer period (May, July) and autumn period (October), that is, in the breeding and postbreeding periods (Fig. 5). This analysis was done for $C$. glareolus on three plots and for $M$. agrestis only on plot A (the number of data was insufficient on the other plots). A. agrarius occurred in the plots mostly in autumn, so it was not possible to include this species. The mean home range size of $C$. glareolus in the springsummer period was larger than in the autumn period on all the plots. The difference is statistically significant for plots S and P. The same was true of $M$. agrestis, though the difference was not statistically signicant. 
In no case individual home ranges covered all trapping points (in each trapping series there were points with no individuals trapped). Significant positive correlation coefficients have been found between the number of trapping points occupied by a species and the abundance of this species (Table 3).

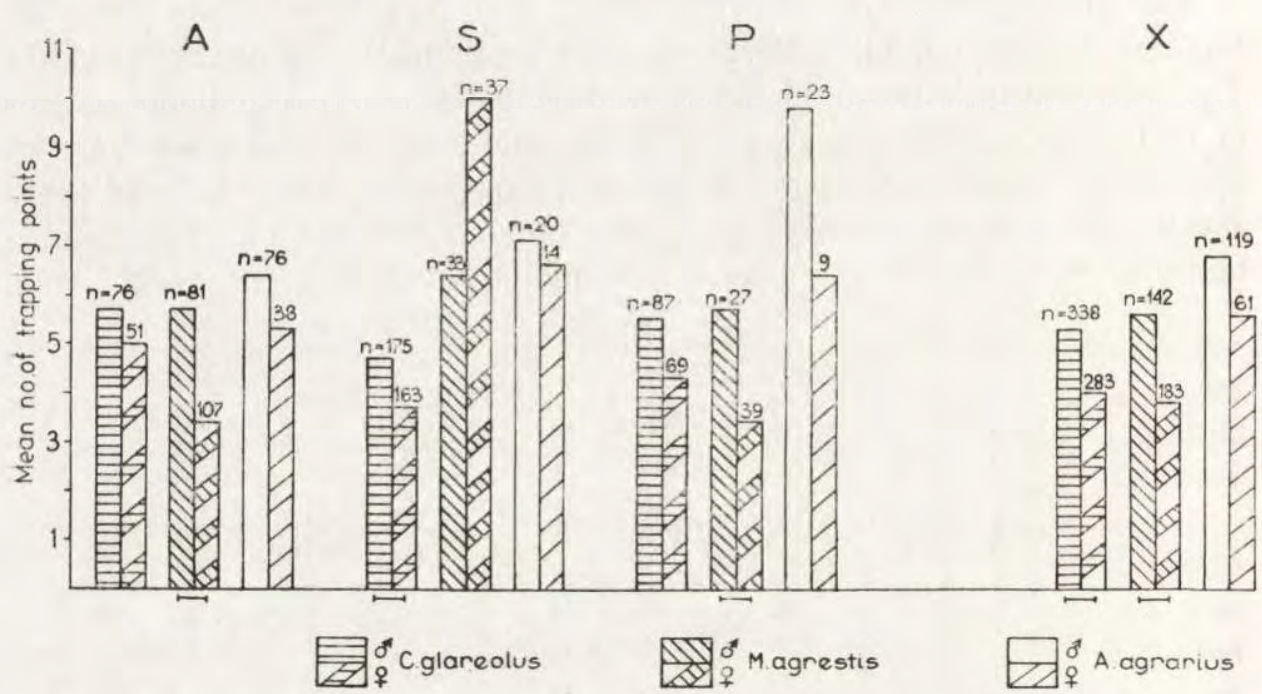

Fig. 4. Mean home range sizes for males and females of different species on plots $\mathrm{A}, \mathrm{S}$, and $\mathrm{P}$.

$\mathrm{X}-$ mean for all the plots jointly, $\mathrm{n}-$ number of individuals. Horizontal lines under the diagram join significantly different $(P<0.05)$ home range sizes.

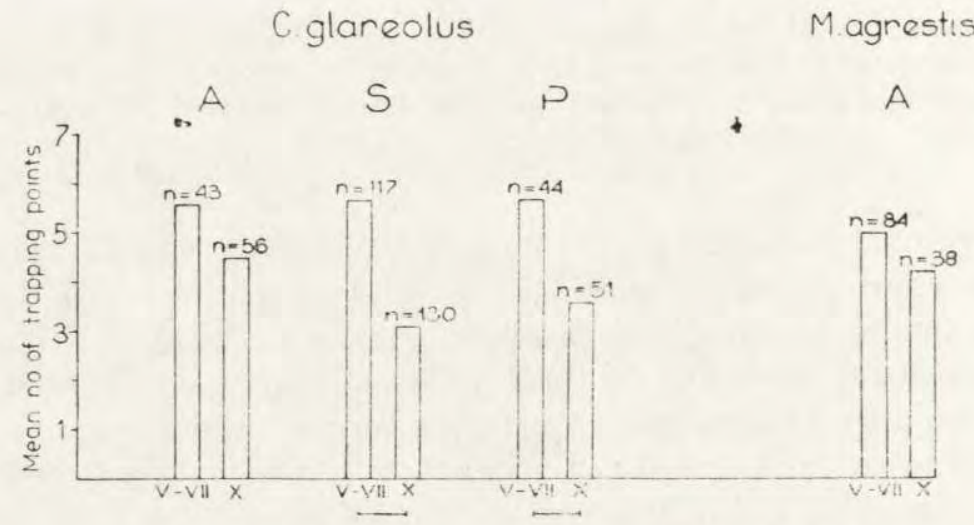

Fig. 5. Mean home range sizes in the spring-summer period (breeding season) and in autumn (postbreeding period) on plots $\mathrm{A}, \mathrm{S}$, and $\mathrm{P}$.

Horizontal lines under the diagram join significantly different $(P<0.05)$ home range sizes, $\mathrm{n}-$ number of individuals. 
An increase in animal numbers can cause not only visits to the points not visited earlier but also an increase in the overlap of individual home ranges. To find an evidence for this, it has been assumed after Andrzejewski (1967) that the overlap can be measured as a mean number of individuals per trapping point. Only the points at which at least one individual was captured in a series were considered. If the mean number of individuals per trapping point is one, home ranges do not overlap at

Table 3

Relationship between the number of trapping points where at least one individual of a given species was captured $(y)$ and the abundance of this species $(x)$ on the study plots.

$r=$ coefficient of rectilinear correlation. All values of $r$ are statistically significant at $P<0.05$.

\begin{tabular}{|c|c|c|c|c|c|c|}
\hline \multirow{2}{*}{ Plot } & \multicolumn{2}{|c|}{ C. glareolus } & \multicolumn{2}{|c|}{ M. agrestis } & \multicolumn{2}{|c|}{ A. agrarius } \\
\hline & $r$ & $y=a x+b$ & $r$ & $y=a x+b$ & $r$ & $y=a x+b$ \\
\hline A & 0.846 & $1.09 x+10.78$ & 0.905 & $0.94 x+7.04$ & 0.826 & $1.34 x+3.88$ \\
\hline S & 0.873 & $0.73 x+16.80$ & 0.888 & $1.25 x+2.81$ & 0.892 & $0.79 x+5.79$ \\
\hline $\mathbf{P}$ & 0.856 & $1.21 x+5.57$ & 0.892 & $1.49 x+0.37$ & 0.820 & $1.21 x+4.19$ \\
\hline
\end{tabular}

Table 4

Relationship between the index of home range overlap ( $y$ - the number of individuals captured at a trapping point) and the abundance of the species $(x)$ on the study plots.

$r=$ coefficient of rectilinear correlation. Statistically significant values of $r$ at $P<0.05$ are boldfaced.

\begin{tabular}{|c|c|c|c|c|c|c|}
\hline \multirow{2}{*}{ Plot } & \multicolumn{2}{|c|}{ C. glareolus } & \multicolumn{2}{|c|}{ M. agrestis } & \multicolumn{2}{|c|}{ A. agrarius } \\
\hline & $r$ & $y=a x+b$ & $r$ & $y=a x+b$ & $r$ & $y=a x+b$ \\
\hline A & 0.659 & $0.02 x+1.25$ & 0.794 & $0.01 x+1.13$ & 0.768 & $0.02 x+1.12$ \\
\hline $\mathrm{S}$ & 0.823 & $0.02 x+1.39$ & 0.707 & $0.02 x+1.09$ & 0.712 & $0.01 x+1.20$ \\
\hline $\mathrm{P}$ & 0.699 & $0.01 x+1.55$ & 0.324 & $0.01 x+1.14$ & 0.357 & $0.01 x+1.17$ \\
\hline
\end{tabular}

all. A value greater than one indicates an overlap of individual home ranges. Changes in the overlap index with increasing population density were analysed (Table 4$)$. Statistically significant $(P<0.05)$ positive correlation coefficients were found, implying that the overlap of home ranges of all the three species increased with their numbers.

\section{CHARACTERISTICS OF THE SPATIAL DISTRIBUTION OF RODENTS}

The spatial distribution of individual species in the community was analysed on the basis of the distribution of the number of animals trapped at particular points in successive years, seasons, and plots. The type of distribution was found using the index $V=\sigma / \bar{x}$ where $\bar{x}$ is the mean number of individuals captured per point, and $\sigma^{2}$ is the variance of the 
mean number of individuals. For $V=1$ the distribution is random, for $V<1$ uniform, and for $V>1$ clumped. The significance of differences between the theoretical and empirical distributions was estimated using the $t$-Student test at $P=0.05$.

It has been found that of all the study species, $C$, glareolus hadl clumped distribution most frequently, especially on plots $\mathrm{S}$ and $\mathrm{P}$. This is shown by a high proportion of cases in which the values of the distribution index are statistically significant in relation to all its values obtained (Table 5). A clumped distribution is also frequent in A. agrarius, and it was least frequent in $M$, agrestis.

\section{MOVEMENTS OF INDIVIDUAL SPECIES WITHIN THE STUDY PLOTS}

Individuals of particular species were captured only on some parts of the study plots. Thus a question arises to what degree particular populations move within the study plots, changing trapping points in time. To answer this question, for each trapping series $(1,2,3, \ldots m)$ the number of points was estimated in which individuals of a given species were trapped $\left(L_{1}, L_{2}, L_{3}, \ldots L_{m}\right)$. Then, the numbers of these points were compared in pairs of successive trapping series ( $L_{1}$ and $L_{2}$, $L_{2}$ and $L_{3} \ldots, L_{t}$ and $\left.L_{m}\right)$. In each of these pairs, the lower number of points was used as a basis $(L)$ when compared with the higher one ( $L \mathrm{~m}$ when $L_{m}<L_{i}$ or $L_{i}$ when $\left.L_{i}<L_{m}\right)$. It was calculated how many trapping points $(n)$ of this basis $(L)$ did not capture animals in the compared trapping series. The index of variability in the place of capture of the population of a given species $(C)$ for particular trapping series was calculated as a ratio of the number of trapping points of the basis which was not occupied by the species (n) to the number of trapping points occupied in the series taken as a basis $(L): C=n / L$.

Then the mean value of this index was calculated for all pairs of trapping series compared for each species and for particular plots over the entire study period (upper part of Table 6). It has been found, that of all the study species, C. glareolus changed the lowest number of trapping points. This is shown by a lower variability index than for other species, when data from all the study plots are analysed jointly (significant differences at $P<0.901$ ). But on plot A, C. glareolus population changed more trapping points than on plots $\mathrm{S}+\mathrm{P}$ (a significant difference at $P<0.001)$. $M$. agrestis population on plot $\mathrm{A}$ changed less trapping points than on the other plots, but the difference is not statisticaly significant. For $A$. agrarius this index could be calculated only on plots $\mathrm{A}$ and $\mathrm{S}$, where its values were similar.

A relationship was examined between the index of variability in 


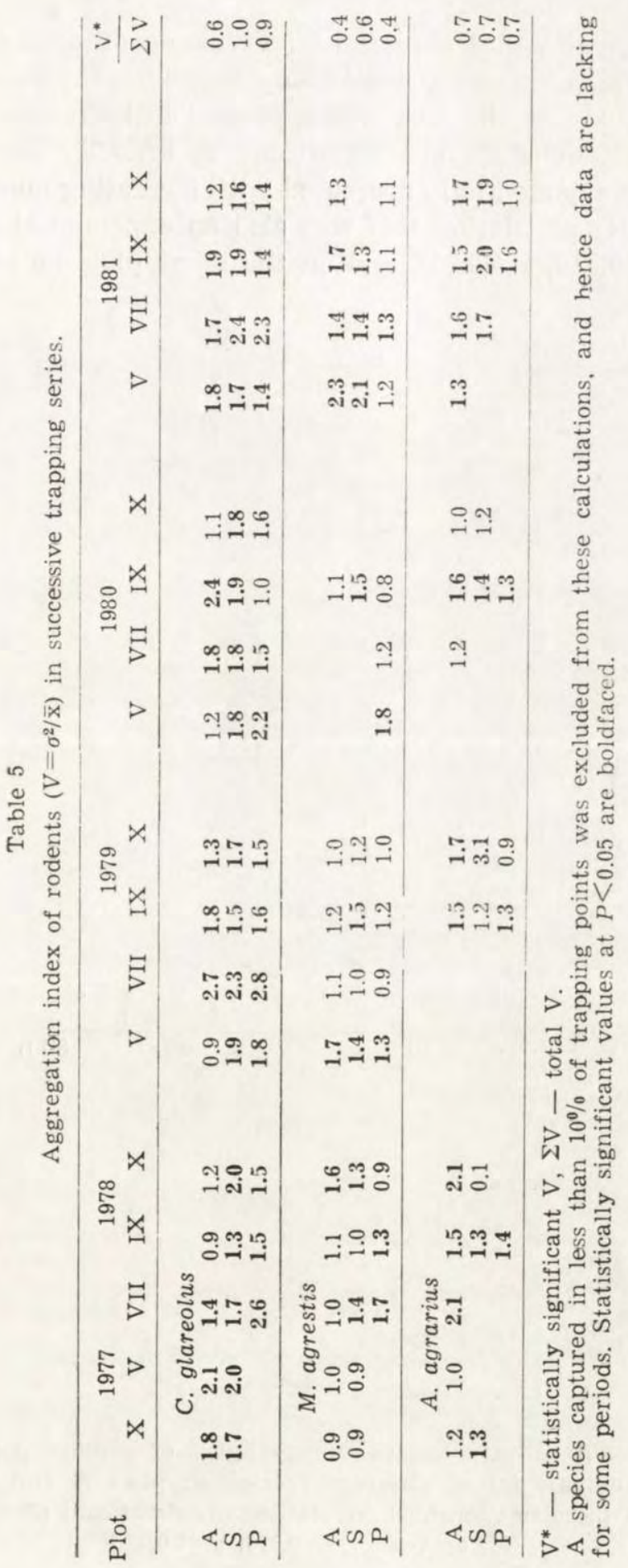


capture points and the number of individuals of particular species. It has been found that such a relationship exists for C. glareolus an plot A $(r=-0.575)$ and on the two other plots jointly $(r=-0.473)$ (Fig. 6). Both these relationships are significant at $P<0.05$. The variability of capture points exponentially decreased with increasing number of animals. For $M$. agrestis population this was also an exponential relationship on plot A $(r=-0.916, P<0.05)$, and on the other plots no relationship was found.
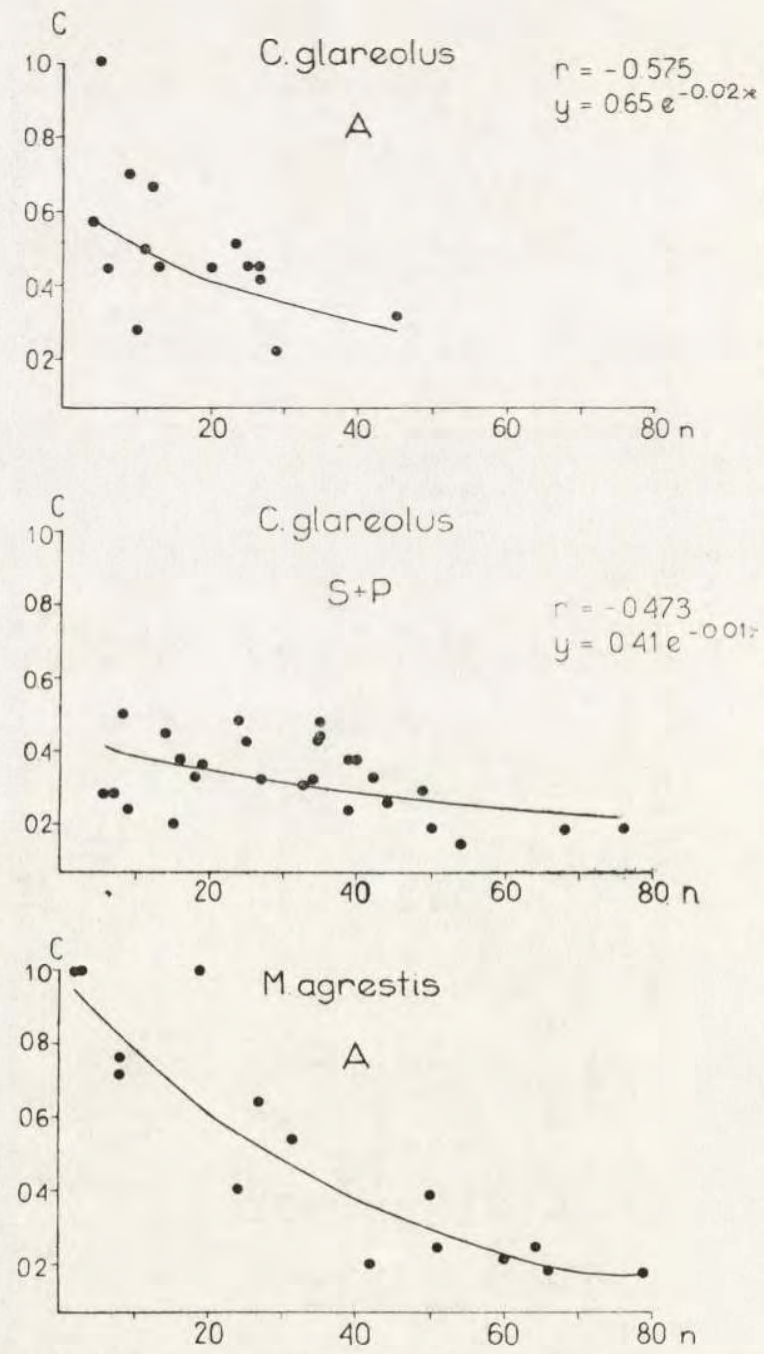

Fig. 6. Relationship between the variability index of capture points (C) and the number of individuals $(\mathrm{n})$ of different species on plots A and S+P: $y=a \cdot e^{b x}$. All these relationships are statistically significant $(P<0.05)$.

M. agrestis, $r=-0.916 ; y=0.99 e^{0.02 x}$ 
It follows from this that differences in the number of individuals of each species could influence the value of $C$ given in the upper part of Table 6. On plot A, the number of $C$. glareolus was the lowest, thus the value of $C$ could be higher than on the other plots. The number of $M$. agrestis on plot A was the highest, thus the values of $C$ could be lower than on the other plots. To compare the value of $C$ at similar numbers of individuals, its mean values were calculated only for the trapping series with less than 45 individuals captured (lower part of Table 6). Subdominant species on particular plots generally did not exceed this number. The values of this index were compared respective the values of $C$ calculated for all numbers of individuals (Table 6). They were similar for the population of $C$. glareolus, while for $M$. agrestis on plot $\mathrm{A}$ the value of $C$ increased significantly $(P<0.05)$ and did not differ from the values of $C$ obtained for other two plots. Thus, it can

Table 6

Mean values of the variability of capture points (C) ( $n$ is the number of trapping series).

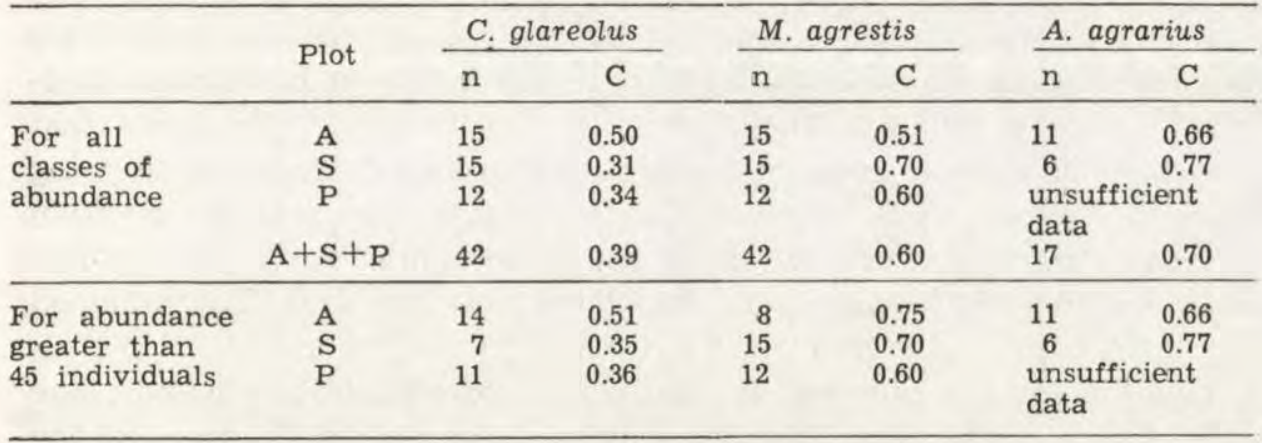

be suggested that the population of $C$. glareolus showed a lower variability in visiting the same trapping points, as compared with the other species, and that in the more degraded habitat (plot A) this variability was higher than in less degraded habitats (plots $\mathrm{S}$ and P). For the other species this index was similar and did not depend on the habitat.

\section{CONSTANCY IN THE ATTRACTIVENESS OF TRAPPING POINTS FOR RODENTS}

On each study plot there were trapping points where no one individual of a given species was captured over the entire study period. The only exception was $M$. agrestis on plot A, where it was trapped at each point at least once. At the same time, this species, was not captured 
at 22 points on plot $\mathrm{S}$ and at 2 points on plot P. C. glareolus was not captured on particular plots at 1 to 3 trapping points, and A. agrarius at 3 to 31 points. Thus, some points were permanently non-attractive to rodents of particular species. Even if population members remain in the same place of the study plots for a long time the attractiveness of trapping points can vary for various reasons.

The number of individuals captured at a trapping point can be used as a measure of attractiveness. The attractiveness of different trapping points can vary from one trapping series to another. As a measure of the constancy in this attractiveness, we can use a correlation coefficient between the number of individuals of one species captured at a given point in one trapping series and their number captured at the same point in the next trapping series. It should be stressed that the matter in question is the recapture of individuals of the same species at the same trapping points, and not the recapture of the same individuals. In most cases this relationship can be illustrated by a linear regression. Statistically significant $(P<0.05)$ positive values of the correlation coefficient were found, indicating that the degree of attractiveness of some trapping points for individuals of the same species can persist for a long time from one trapping series to another. In the cases where the coefficients of linear correlation were not significant, the nonlinear correlation coefficients were calculated. They were not significant which shows that the degree of attractiveness of trapping points varied from one trapping series to another. Correlation coefficients higher than 0.19 (at $P=0.05$ ) are statistically significant for each plot, as the number of trapping points for which the coefficients were calculated was identical. The obtained significant values of correlation coefficients $(r)$ ranged from 0.21 to 0.51 .

The higher the number of significant correlation coefficients, the longer the attractiveness of trapping points is preserved. To compare the constancy of the attractiveness of trapping points for each species on particular plots in different years in successive series of trapping, the proportion of the number of cases (n) with a significant value of the correlation coefficient $\left(n_{r}{ }^{*}\right)$ in the total number of the correlation coefficients $\left(n_{r}\right)$ was calculated.

The attractiveness of trapping points was the most stable for C. glareolus on all the study plots. This is shown by a higher proportion of the number of significant correlation coefficients (Fig. 7). A comparison of the significance of differences between species on particular plots was not possible because the number of the correlations analysed was too low.

It seems that the attractiveness of the trapping points for $C$. glareolus was the most constant on plots $\mathrm{S}$ and $\mathrm{P}$, and it varied most frequently 
on plot A (Fig. 7). These differences, however, are not statistically significant, which can be due to a low number of the coefficients analysed. The constancy of the attractiveness of trapping points for $M$. agrestis was lower than for C. glareolus on each plot (Fig. 7).

A. agrarius was present on the study plots in spring only on rare occasions. For this reason the constancy of the attractiveness of trapping points to this species was analysed mostly in September and October. On all the study plots jointly, only one out of 19 correlation coefficients was statistically significant. On plots $\mathrm{A}$ and $\mathrm{S}$ no constancy was found at all for A. agrarius.

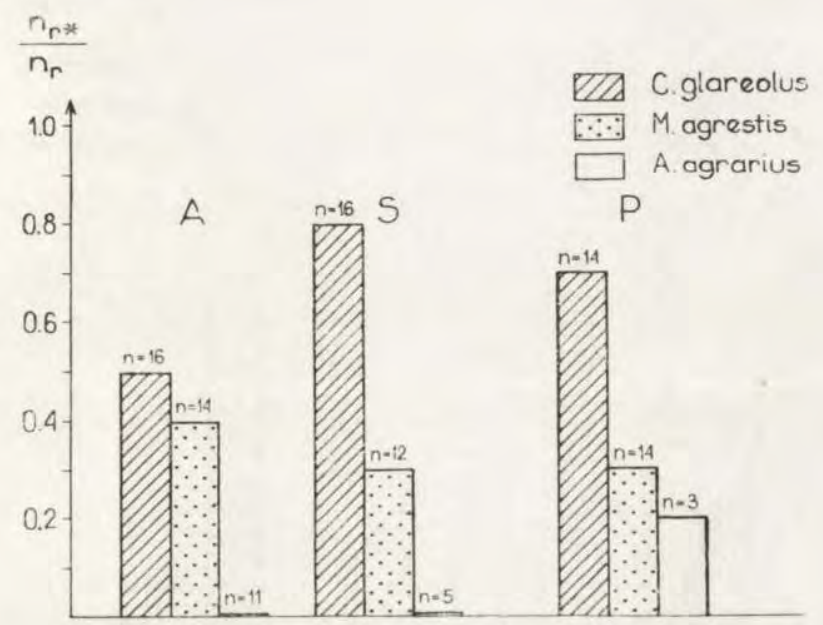

Fig. 7. Constancy of the attractiveness of trapping points in successive trapping series on plots $\mathrm{A}, \mathrm{S}$, and $\mathrm{P} \frac{n_{r}^{*}}{n_{r}}$, where $n_{r}^{*}$ is the number of cases $(n)$ with a significant correlation coefficient $\left(r^{*}\right)$ between the number of individuals of a given species captured in two successive trapping series at the same trapping point. $n_{r}$ is the number of all the correlation coefficients analysed.

A comparison of all the three species on all the plots jointly shows that the attractiveness of trapping points was the most stable for C. glareolus. For this species $70 \%$ of the total number of 46 correlation coefficients were statistically significant, while only $30 \%$ of 40 correlation coefficients for $M$. agrestis, and only $5 \%$ of 19 correlations for A. agrarius. Differences between all these species are statistically significant $(P<0.01)$.

It can be assumed that the attractiveness of trapping points to rodents depends on the phenology of surrounding plants. Thus, some patches of the herb layer could be preferred in spring and other patches in autumn. 
To find whether or not the populations of individual species occupy the same places in the same seasons of different years with similar intensity, a correlation coefficient was calculated between the number of individuals captured at particular trapping points in a trapping series each month and the number of individuals captured in the same place the following year.

It has been found that the agree of attractiveness of particular places was most similar in the same seasons of different years for C. glareolus. This is shown by a higher proportion of significant correlation coefficients $\left(n_{r}\right)$ in the total number of the coefficients analysed (Fig. 8).

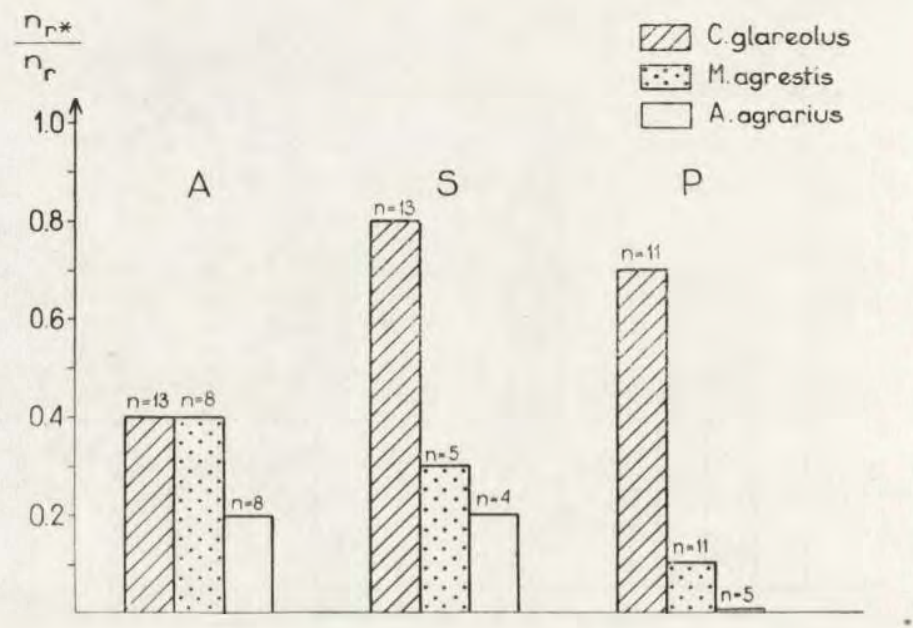

Fig. 8. Constancy of the attractiveness of trapping points in corresponding periods of different years on plots $\mathrm{A}, \mathrm{S}$, and $\mathrm{P}$.

$n_{r^{*}}$ is the number of cases $(n)$ with a significant correlation coefficient $\left(r^{*}\right)$ between the number of individuals of a given species captured at a given trapping point in one series and the number of individuals captured at the same point in the corresponding period of the following year, $n_{r}$ is the number of all the correlation coefficients analysed.

On plot A this proportion was not so high. The constancy of the attractiveness of particular places from one year to another for C. glareolus was maintained over the growing season on plots S and P. On plot A, however, this species was less attached to the same places. Only in July, all the three correlation coefficients for pairs of successive years were statistically significant, while none in October.

The constancy of the attractiveness of the same trapping points for $M$. agrestis and $A$. agrarius was generally lower than for $C$. glareolus. 
9. RELATIONSHIPS IN THE DISTRIBUTION OF CO-OCCURRING POPULATIONS OF THE STUDY SPECIES

The co-occurrence of species was examined in pairs of species inhabiting the same area, at each trapping point. The CMA index (Cole's Measure of Association) was used (Cole, 1949). The following formulae were used for calculations:

$$
\begin{aligned}
& \text { if } a d \geqslant b c \quad \quad C M A \pm \sigma=\frac{a d-b c}{(a+b)(b+d)} \pm \sqrt{\frac{(a+c)(c+d)}{\mathrm{n}(a+b)(b+d)}} \\
& \text { if } b c>a d \text { and } d \geqslant a C M A \pm \sigma=\frac{a d-b c}{(a+b)(a+c)} \pm \sqrt{\frac{(b+d)(c+d)}{\mathrm{n}(a+b)(a+c)}} \\
& \text { if } b c>a d \text { and } a>d C M A \pm \sigma=\frac{a d-b c}{(b+d)(c+d)} \pm \sqrt{\frac{(a+b)(a+c)}{\mathrm{n}(b+d)(c+d)}}
\end{aligned}
$$

where:

$a$ - the number of trapping points where the two species were captured,

$b$ - the number of trapping points where only the first species of the pair was captured,

$c$ - the number of trapping points where only the second species of the pair was captured,

$d$ - the number of trapping points where no species of the analysed pair was captured.

It has been assumed that the trapping points where at least one of the three study species was captured are attractive to each of them. Trapping points where rodents were not captured at all in a trapping series are excluded from this analysis. Only these trapping series are considered in which each of the species in the pair occupied not less than $10 \%$ of the trapping points. The value of CMA can vary from -1 to +1 . Its negative value shows that individuals of the two species do not tend to co-occur, and the positive value shows that they tend to co-occur in the same places. The $\chi^{2}$ test was used for significance of the CMA values.

It has been found that generally all the species tended to show a negative association at trapping points. This is indicated by negative values of the CMA index in most of the trapping series. The proportion of the trapping series with negative values, though not always statistically significant, was $94 \%$ for the pair C. glareolus and M. agrestis, $83 \%$ for $C$. glareolus and $A$. agrarius, and $73 \%$ for $M$. agrestis and A. agrarius.

A total value of the CMA index over the entire study period was estimated for each pair of species (Fig. 9). The pair C. glareolus, M. agre- 
stis was characterized by the lowest CMA on each plot, as compared with other pairs.

Comparing different plots, it has been found that the pairs C. glareolus, A. agrarius and C. glareolus, $M$. agrestis were most negatively associated on plot $\mathrm{P}$, and least negatively on plot A.

The value of CMA was analysed in different seasons for each pair separately (Fig. 10a) and for all pairs jointly (Fig. 10b) on each plot. This analysis showed a seasonal variability of the CMA index for all pairs on plot A. The negative association of paired species declined from spring to autumn, implying that the mutual tolerance increased. The pair C. glareolus, M. agrestis showed similar seasonal changes on the other

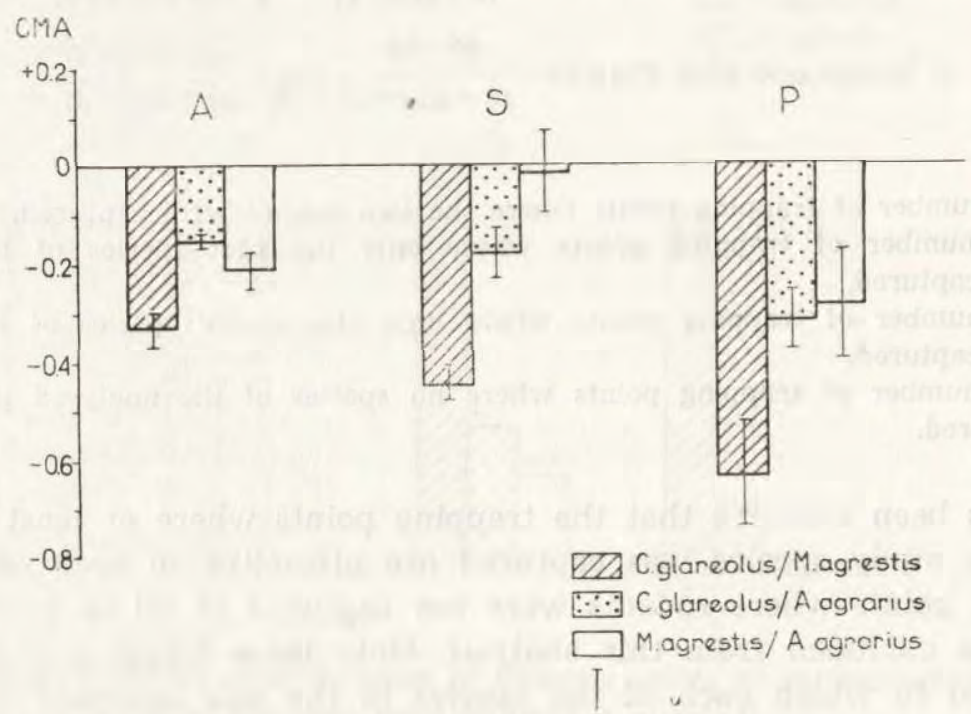

Fig. 9. Values of the CMA index (Cole's Measure of Association after Cole, 1949) for different species pairs on plots A, S, and P over the entire istudy period. $\sigma$ is standard deviation.

plots (Fig. 10a). For pairs C. glareolus, A. agrarius and M. agrestis, $A$. agrarius no clear seasonal changes were observed on plot $\mathrm{S}$ (Fig. $10 \mathrm{a}, \mathrm{b})$, and only on this plot positive values of the CMA index were recorded in July and August. A. agrarius was absent from plot $\mathrm{P}$ in spring and summer, making the analysis impossible.

\section{DISCUSSION}

Forests of the study area represented a suitable habitat for rodents, though plant communities were degraded and destroyed by coal industry. These were fertile, humid forests, with a high plant species diversity, 
frequently covered with dense, tall ferns, raspberry and blackberry bushes (Celiński \& Wika, 1980). Dying fallen trees, branches and trunks provided excellent hiding and nesting sites. In our view, such a habitat can satisfy food requirements and provide shelters for many rodent species, including those typical of forests, like C. glareolus, mid-forest meadows, like $M$. agrestis, and associated with crop fields and shrubberries, invading forests mainly late in summer and in autumn, like A. agrarius.

The study areas were located in an intensely industrialized region of the country, in more or less degraded forests (Celiński \& Wika, 1980),
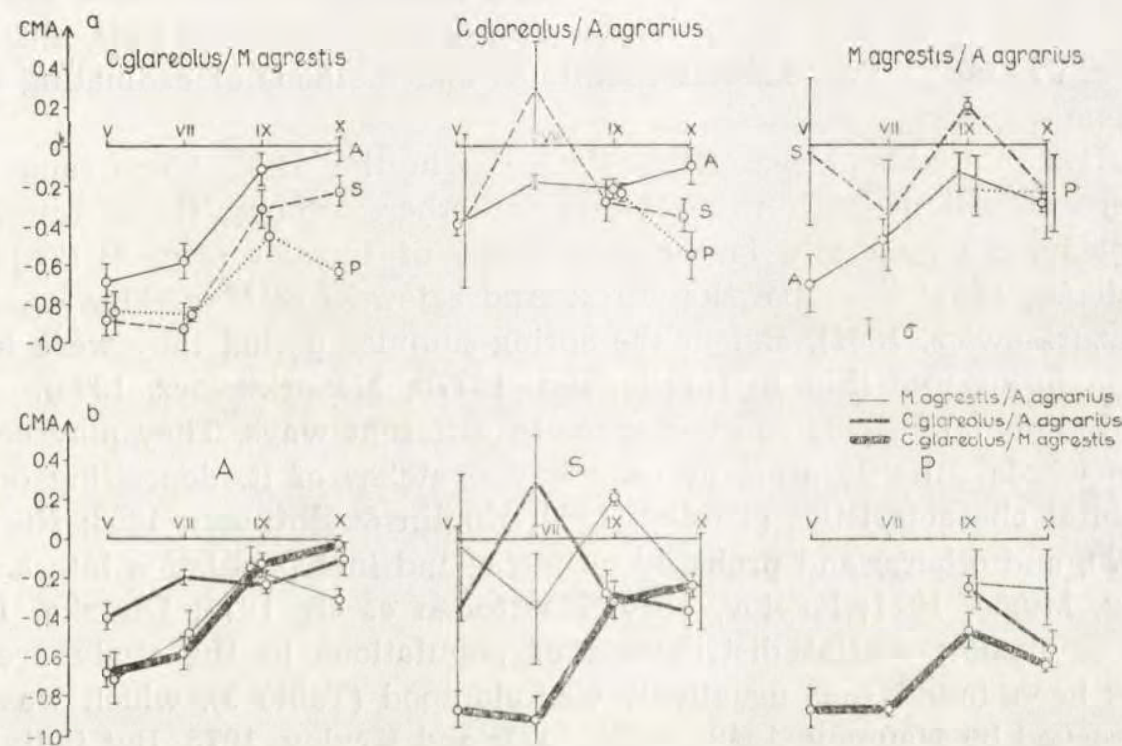
P

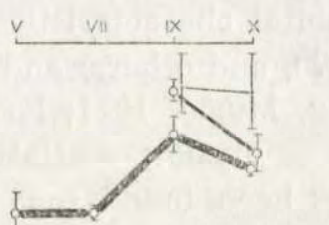

Fig. 10. Seasonal changes in the CMA index for pairs of species on plot A, S, and P. (a) pairs of species, (b) plots, $\sigma$ is standard deviation, $\mathrm{O}-$ statistically significant $(P<0.05)$ CMA values, - statistically nonsignificant CMA values.

where the number of rodents in the autumn peak was high, as compared with other regions of Poland (Walkowa et al., 1982).

All indices of spatial distribution were based on captures of animals. The trappability of the study species was high, though there were differences in the attractiveness of the bait (oats) for particular species. Even herbivorous $M$. agrestis was captured per 2.4 censuses, on the average, $C$. glareolus was captured every 1.7 censuses, and the granivorcus $A$. agrarius every 1.9 censuses (unpublished data).

Hean home range sizes of particular species were in the range of 
the lowest values for the same species in other areas (Brown, 1956; Saint Girons, 1960; Wierzbowska, 1972; Andrzejewski \& Mazurkiewicz, 1976; Viitala, 1977; Bashenina, 1981, and others).

In the habitats rich in food, home ranges of rodents are smaller than in poor habitats (Golikova, 1958; Nikitina \& Merkova, 1963; Andrzejewski \& Mazurkiewicz, 1976; and others). Low home range sizes found in our study could be an effect of a high food supply and a high abundance of shelters. On the other hand, high numbers of individuals in the study populations could also account for a decreases in the home range size (Nikitina \& Merkova, 1963; Zejda \& Pelikźn, 1969; Bazurkiewicz, 1981 , and others).

But the comparison of mean home range sizes with those obtained by other authors is difficult because of different methods, different sizes of study plots, habitat conditions and methods of estimating home range size.

Sex-related and seasonal differences in the mean home range size were consistent with those found by other authors. Home ranges of males were generally larger than those of females (Fig. 4) (Zejda \& Pelikán, 1969; Wierzbowska, 1972; Andrzejewski \& Mazurkiewicz, 1976; Mazurkiewicz, 1981), and in the spring-summer period they were larger than in autumn (Fig. 5) (Myllymäki, 1977b; Mazurkiewicz, 1978).

Individual species can use space in different ways. They may occupy the whole suitable area, or only some patches of it, depending on the habitat characteristics (Turček, 1960; Koplin \& Hoffman, 1968; Nikitina, 1970 , and others) and probably on intra- and interpopulation interactions (e.g. Murie, 1971; Krylov, 1975; Henttonen et al., 1977; Dienske, 1979).

Analysing spatial distribution of populations in the study area, it has been found that usually it was clumped (Table 5), which was also observed by Naumov, 1948; Bock, 1972; and Krylov, 1975. But individual populations differed from one another. Clumped distribution was observed least frequently for $M$. agrestis and most frequently for $C$. glareolus. This was true in different seasons, thus at different densities. It can be thus suggested that the clumped distribution of C. glareolus was not related to the abundance of this species. Also Mazurkiewicz (1981) found no relationship between the distribution pattern of this species and its population size.

The characteristics of spatial distribution of individual species are compared in Table 7. A four-degree scale was used to present the values of different indices. For a better ilustration of differences between species, the variability index of capture points is presented as its reciprocal, that is, the constancy of trapping points visited.

This comparison shows that: (1) The spatial structure of the C. gla- 
reolus population clearly differed from that of other species. Most often the distribution of this population was clumped, its members more frequently visited the same places on the plots than the members of other populations, and the attractiveness of particular points was most fixed to them. A. agrarius and $M$. agrestis showed much lower values of these indices, and no unequivocal differences in their spatial structure

Table 7

Characteristics of the spatial distribution of rodent populations.

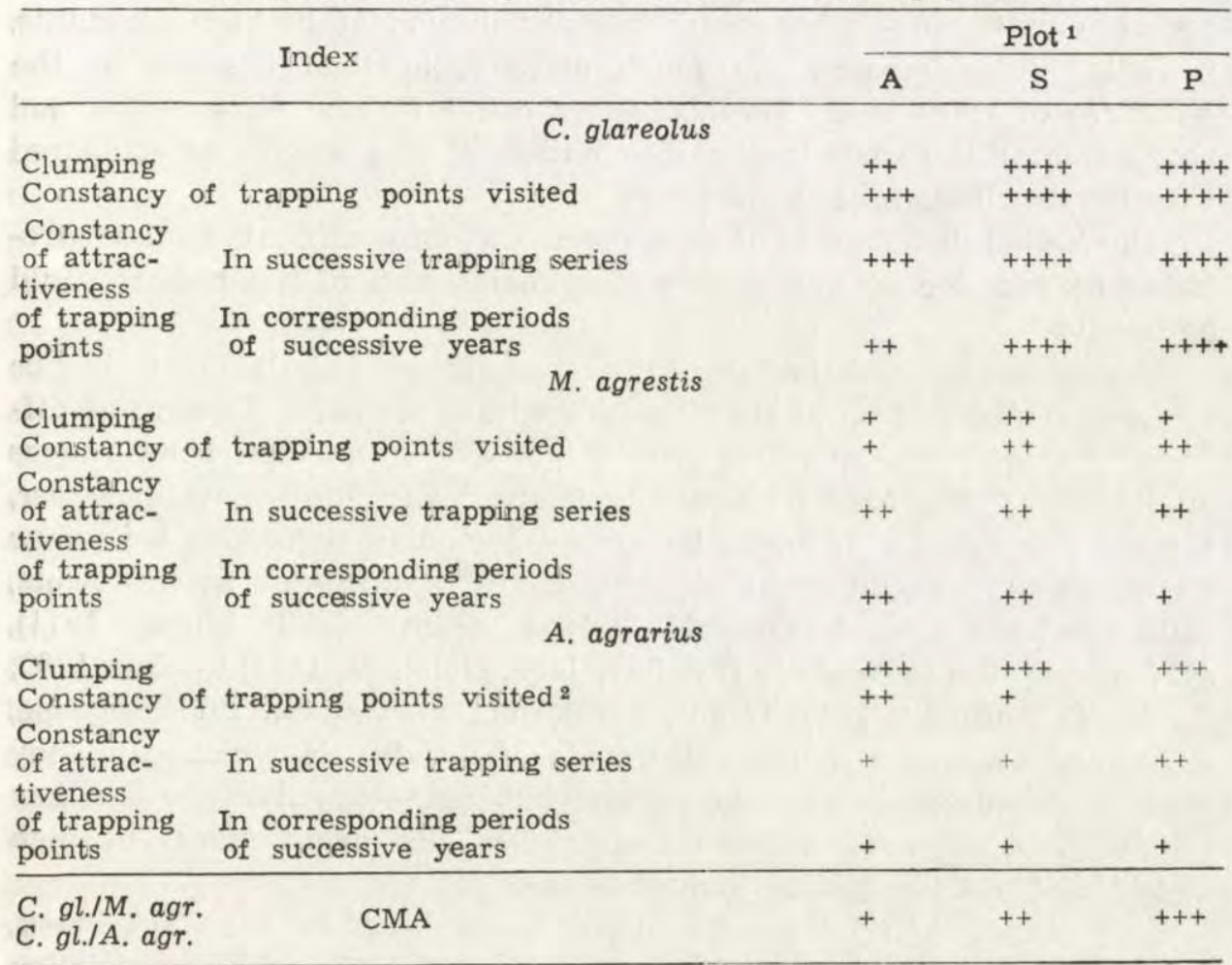

1 The lowest value of the index are denoted by one symbol and the highest ones by four symbols; ${ }^{2}$ Unsufficient data for plot P were collected.

were observed. (2) C. glareolus population exhibited the most pronounced response to the degradation of plant communities, all indices for this species being lower on plot A, as compared with the other plots. $M$. agrestis and $A$. agrarius showed a similar behaviour on all the plots.

C. glareolus is a forest dwelling species, and the structure of the tree layer is a factor influencing its distribution (Mazurkiewicz \& Rajska-Jurgiel, 1978). The effect of this factor is relatively permanent (long-term). Although the most degraded habitat (plot A) seemed to be 
equally suitable as the other plots (S and $\mathrm{P}$ ) in terms of food and shelters, its most rapid transformation is likely to change the distribution of habitat features important to C. glareolus. This is reflected in changes in the attractiveness of the sites occupied by this species on plot $\mathrm{A}$, which were more frequent than on the other plots. This could also be one of the reasons for more frequent movements of the $C$. glareolus population within this plot and account for a decrease in the value of the agregation index for this species.

The occurrence of $M$. agrestis in forests is related to the degree of coverage with grass. Changes in the distribution of herbaceous plants, including juicy grasses, are much more rapid than changes in the structure of tree stand. These changes can influence $M$. agrestis, and account for differences in the distribution of this species as compared with the distribution of C. glareolus.

The spatial distribution of $A$. agrarius was most difficult for interpretation because we do not know which components of the habitat could be involved.

It may be expected that also interactions among populations influence the spatial distribution of these species within the plots. Capture of different species at the same trapping points shows that their home ranges overlap, thus they may be mutually tolerant. Literature data, however, provide evidence for agonistic behaviour, including aggressive behaviour during direct encounters of representatives of different species (Getz, 1962; Andrzejewski \& Olszewski, 1963; Grant, 1970; Murie, 1971), avoidance in the same areas (Findley, 1954; Golikova, 1957; Turček, 1960; Koplin \& Hoffman, 1968; Grant, 1972; Henttonen et al., 1977; Dienske, 1979), and avoidance in the daily cycle of activity, in which case they may be captured at the same point but not encounter one another (Miller, 1955; Brown, 1956). Some species also avoid places of high densities of another species (Montgomery, 1981).

Our analysis of interspecific interactions is based on the CMA index. This index provides information on the negative or positive association of species at the same trapping points. It is difficult, however, to identify the reasons for negative association. These may be habitat-related differences at particular trapping points, or an effect of competition for food, nesting sites, or other habitat components. The largest differences in food requirements are between $M$, agrestis and $A$. agrarius. The former prefers herbaceous plants, especially grasses (Evans, 1973; Stenseth et al., 1977), the latter seeds and animal food, especially in autumn (Babińska-Werka, 1981; Obrtel \& Holišova, 1981). If the negative association of different species at trapping points is related to an uneven distribution and low overlap of different food types at these points, this 
pair of species should show the highest lack of co-occurrence: M. agrestis would be trapped at points with grass, while A. agrarius at points rich in seeds. But these two species did not show a greater lack of cooccurrence than the other pairs of species (Fig. 9), implying that not differences in the distribution of food determined the lack co-occurrence of these species at trapping points. From rather rich literature data (Drożdż, 1966; Hansson, 1971; Zemanek, 1972; Gębczyńska, 1976; Babińska-Werka, 1981; Obrtel \& Holišova, 1981; and others), it can be concluded that the diets of the pairs C. glareolus, M. agrestis, and C. glareolus, A. agrarius partly overlap. Thus, it cannot be excluded that the competition for food can contribute to the avoidance of these species. Perhaps, a comparison of the spatial distribution of plants and rodents on the study plots, combined with an analysis of their stomach content to assess their food preference, which is planned by the authors, will provide a deeper insight into this problem.

Interspecific antagonisms can also be related to nesting sites. Generally C. glareolus does not burrow, and it uses natural hollows in the ground under roots of trees, or places of litter accumulation as shelters (Daniel et al., 1970; Albov et al., 1979), and it is more frequently captured in places with large amounts of dead plant material (Turček, 1960). M. agrestis nests are in burrows, but also in clumps of shrubs and grasses, especially in damp places (Ognev, 1950). A. agrarius also utilizes burrows (Karaseva, 1979). Thus, in addition to the overlap in food niches, also similarity in their nesting sites can intensify interactions between C. glareolus and $M$, agrestis, especially in spring, when soil moisture is high. The drying of soil and changes in the diet of these two species can reduce conflicts.

In this view, it seems that the CMA index is a good measure of interspecific relationships. Generally all the species in pairs on the study plots tended to avoid one another, this being most clearly pronounced in the pair C. glareolus, M. agrestis (Fig. 10a). The avoidance in this pair was particularly acute in spring. It declined in autumn, which implies an increase in tolerance, though also then they tended to avoid one another. Henttonen et al. (1977), Myllymäki (1977a), and Hansson (1983) have found competitive interactions between these species as well.

Also C. glareolus and A. agrarius avoided one another at trapping points, though there were differences from season to season and from one plot to another. On plot A, tolerance between these two species increased in autumn, while on plot S clearly negative interactions were observed only in autumn (Fig. 10b).

There are scarce literature data on interactions between C. glareolus and A. agrarius. Using the CMA index, Gliwicz (1981) has found that 
these two species tend to avoid one another but independent of the season.

A decrease in the avoidance between $A$. agrarius and $M$. agrestis from spring to autumn was observed only on the most degraded plot (A). On plot $\mathrm{S}$, even a positive value of the CMA index was noted for these species in September. There are no literature data for this pair for comparison.

The occurrence of $M$. agrestis and $A$. agrarius in larger numbers on plot $\mathrm{A}$, as compared with the other plots, seems to be explained by the fact that this was the most suitable habitat to them, though most transformed and polluted. It is difficult, however, to understand why the density of C. glareolus was low there, despite presumably suitable habitat conditions for this species as well.

As the tendency to avoidance was the strongest in the pair C. glareolus, $M$. agrestis, as compared with the other pairs of species under study, it may be suggested that a large number of $M$. agrestis on plot A limited the number of C. glareolus. This thesis is supported by their population dynamics on the other two plots, where the number of $M$. agrestis was much lower and generally $C$. glareolus predominated by number. On the other hand, a lower abundance of $C$. glareolus on plot A could facilitate a partial use of the same trapping points by both C. glareolus and $M$. agrestis (e.g. through avoidance in the daily cycle), accounting for lower values of the CMA index for these two species on this plot, as compared with the other plots.

As all the pairs of species showed a decreased avoidance on plot A, it may be suggested that if habitat conditions are suitable to any of these species, it will gain a dominant position more easily than on the other plots. This may indicate that the rodent community was less stable and integrated on plot A, as compared with the other plots, which is consistent with the hypothesis of Walkowa et al. (1982). This hypothesis is based on generally higher numbers of rodents on the degraded plot A in autumn, a higher amplitude of changes in numbers, and a more frequent displacement of dominant species.

\section{REFERENCES}

1. Andrzejewski R. \& Olszewski J., 1963: Social behaviour and interspecific relations in Apodemus flavicollis (Melchior, 1834) and Clethrionomys glareolus (Schreber, 1780). Acta theriol., 7: 155-168.

2. Andrzejewski R., 1967: An attempt at empirical veryfication of the relation between density and average coverage of the home range and their values. Ekol. pol., A, 15: 747-753.

3. Andrzejewski R. \& Wierzbowska T., 1970: Estimates of the number of traps 
visited by small mammals based on a probabilistic model. Acta theriol., 15: $1-14$.

4. Andrzejewski R. \& Mazurkiewicz M., 1976: Abundance of food supply and size of bank voles home range. Acta theriol., 21: 237-253.

5. Andrzejewski R. \& Simonides S., 1982: Organizacja przestrzenna populacji roślin i zwierząt. Wiad. ekol., 28: 87-124.

6. Albov S. A., Karulin B. E. \& Khljap L. A., 1979: Ispolzovanie ubežišč ryžej polevkoj (Clethrionomys glareolus) po dannym radioizotopnogo mečenija. Zool. Ž., 58: 241-247.

7. Babinska-Werka J., 1981: Food of the striped field mouse in different types urban green areas. Acta theriol., 26: 285-299.

8. Bashenina N. V., ed. 1981: Evropejskaja ryžaja polevka. Izd. Nauka: 1-351. Moskva.

9. Bock E., 1972: Use of forest associations by bank vole population. Acta theriol., 17: 203-219.

10. Brown L. E., 1956: Field experiments on the activity of the small mammals, Apodemus, Clethrionomys and Microtus. Proc. Zool. Soc., London, 112: 549-564.

11. Celiński F. \& Wika S., 1980: Preliminary studies on degradation of forest habitats near Knurów (Silesia). Pol. ecol. Stud., 4: 593-606.

12. Celiński F., Wika S. \& Baron H., 1982: Vegetation of Knurów town and its surrounding with trends of multiannual changes. Pol, ecol. Stud., 8: 241-258.

13. Chełkowska H., 1969: Numbers of small rodent in five plant associations. Ekol. pol., A, 17: 847-854.

14. Cole L. C., 1949: The measurement of interspecific association. Ecology, 30: $411-424$.

15. Daniel M., Mrčiak M., Rosický B., 1970: Location and composition of nests built by some central European insectivores and rodents in forest biotopes. Acta. Fac. Rerum Nat. Univ, Comeniane, Zool., 16: 1-35.

16. Dienske H., 1979: The importance of social interaction and habitat in competition between Microtus agrestis and $M$. arvalis. Behaviour, 71: 1-26.

17. Drożdż A., 1966: Food habits and food supply of rodents in the beech forest. Acta theriol., 11: 363-384.

18. Evans D. M., 1973: Seasonal variations in the body composition and nutrition of the vole Microtus agrestis. J. Anim. Ecol., 42: 1-18.

19. Foik H., 1978: Wstępna analiza mikroklimatu i zanieczyszczeń powietrza oraz wód powierzchniowych. Mechanizmy funkcjonowania wybranych krajobrazów Górnośląskiego Okręgu Przemysłowego i Rybnickiego Okręgu Węglowego. Inst. Ekol. PAN Dziekanów Leśny: 18-31. Mimeogr.

an. Findley J. S., 1954: Competition as a possible limiting factor in the distribution of Microtus. Ecology, 35: 418-420.

21. Flint V. E., 1977: Prostranstvennaja struktura populacij melkih mlekopitajušcih. Izd. Nauka: 1-181. Moskva.

22. Getz L. L., 1962: Aggressive behaviour of the meadow and prairie voles. J. Mammal., 43: 351-368.

23. Gębczyńska Z., 1976: Food habits of the bank vole and fenological phases of plant in an oak hornbeam forest. Acta theriol., 26: 223-236.

24. Gliwicz J., 1981: Competitive interaction within a forest rodent community in central Poland. Oikos, 37: 353-362.

25. Golikova V. L., 1957: Vlijanie mežvidovyh otnošenij na rasprostranenie lesnyh myševidnyh gryzunov vnutri areala. Izd. Lvovskogo Univ.: 1-71, Lvov. 
26. Golikova V. L., 1958: Zamietki po ekologii populacii lesnyh myšej i ryžih polevok. Tr. nauč-proizvod. Konf. Zašč. Rast. od Vred. i Boleznej na Jugo-vostoke, Saratov.

27. Grant P. R., 1970: Experimental studies of competitive interaction in a two-species system. II. The behaviour of Microtus, Peromyscus and Clethrionomys species. Anim. Behav., 18: 411-426.

28. Grant P. R., 1972: Interspecific competition among rodents. Ann. Rev. Ecol. Syst., 3: $79-106$.

29. Hansson L., 1971: Habitat, food and population dynamics of the field vole, Microtus agrestis (L.) in South Sweden. Viltrevy, 8: 268-378.

30. Hansson L., 1983: Competition between rodents in successional stages of taiga forest: Microtus agrestis vs. Clethrionomys glareolus. Oikos, 40: 258-266.

31. Henttonen H., Kaikusalo A., Tast J. \& Viitala J., 1977: Interspecific competition between small rodents in subarctic and boreal ecosystems. Oikos, 29: $581-590$

32. Karaseva E. V., 1979: Sistematičeskij obzor mlekopitajuščih kak nositelej boleznej. Apodemus agrarius Pallas, 1771 - polevaja myš. [In: "Medicinskaja teriologija", Kucheruk V. V., ed.] Nauka: 194-203. Moskva.

33. Koplin J. R. \& Hoffman R. S., 1968: Habitat overlap and competitive exclusion of voles (Microtus). Am. Middl. Nat., 80: 494-507.

34. Kovalevskij J. \& Korenberg E. I., 1980: Prostranstvennaja struktura populacii lesnyh myševidnyh gryzunov. Fauna i Ekologija Gryzunov, 14: 105-149.

35. Krylov D. G., 1975: Tendency to grouping in spatial distribution of small mammals in a forest habitat. Ekol. pol., 23: $335-345$.

36. Mazurkiewicz M., 1978: Organizacja przestrzenna populacji drobnych gryzoni (na przykładzie nornicy rudej, Clethrionomys glareolus, Schreber, 1780). Wiad. ekol., 24: $377-390$.

37. Mazurkiewicz M. 1981: Spatial organization of a bank vole population in years of small or large numbers. Acta theriol., 26: 31-45.

38. Mazurkiewicz M. \& Rajska-Jurgiel E., 1978: Size and structure of rodent community of various forest stand types. Bull. Acad. Pol. Sci. C1. II., Ser. Sci. biol., 26: 669-677.

39. Miller R. S., 1955: Activity rhytms in the wood-mouse, Apodemus sylvaticus and bank vole, Clethrionomys glareolus. Proc. zool. Soc., 125: 505-515.

40. Montgomery W. I., 1981: A removal experiment with sympatric populations of Apodemus sylvaticus (L.) and A. flavicollis (Melchior). Oecologia, 51: $123-132$.

41. Murie J. O., 1971: Behavioral relationships between two sympatric voles (Microtus) relevance to habitat selection. J. Mammal., 52: 181-186.

42. Myllymäki A., 1977: Interaction between the field vole Microtus agrestis and its microtine competitors in Central Skandinavian populations. Oikos, 29: $570-580$.

43. Naumov N. N., 1948: Očerki sravnitelnoj ekologii myševidnyh gryzunov. Izd. AN SSSR: 1-202. Moskva-Leningrad.

44. Nikitina N. A., 1970: O postojanstve ispolzovanija territorii gryzunami. Fauna i ekologija gryzunov, 9: 110-134.

45. Nikitina N. A. \& Merkova M. A., 1963: Ispolzovanie territorii myšami i polevkami po dannym mečenija. Bjul. Mosk. Obšc. Isp. Prir., Biol., 48: 15-21.

46. Obrtel R. \& Holišova V., 1981: The trophic niche of Apodemus agrarius in northern Moravia. Folia Zool., 30: 11-21. 
47. Ognev S., 1950: Zveri SSSR i prilezaščih stran. 7. Gryzuny. Izd. Akad. Nauk SSSR: 1-706. Moskva-Leningrad.

48. Saint-Girons M. Ch., 1960: Espace vital et comportement territorial chez Apodemus sylvaticus, Clethrionomys glareolus et Microtus agrestis. Relation avec les populations cycliques (1). Vie et Milieu, 11: 233-260.

49. Stenseth N. C., Hansson L. \& Myllymäki A., 1977: Food selection of the field vole, Microtus agrestis. Oikos, 29: 511-524.

50. Turček F. J., 1960: Sidelné vstahy nekotorych lesnych hlodavcov zistené na podklade mapovania. Biológia, Bratisl., 15: 729-736.

51. Walkowa W., Adamczyk K. \& Chelkowska H., 1982: Number and structure of rodent communities in the forest environment of Silesia. Pol. ecol. Stud., 8: $305-330$.

52. Warteresiewicz M., 1979: Oddzialywanie zanieczyszczenia powietrza dwutlenkiem siarki na wybrane gatunki roślin w rejonie Górnośląskiego Okręgu Przenysłowego. Arch. Ochr. Srod., 1: 95-166.

53. Wierzbowska T., 1972: Statistical estimation of home range size of small rodents. Ekol. pol,, 20: 781-831.

54. Viitala J., 1977: Social organization in cyclic subarctic populations of the vole Clethrionomys rufocanus (Sund.) and Microtus agrestis (L.) Ann. zool. Fennici, 14: $53-93$.

55. Zemanek M., 1972: Food and feeding habits of rodents in a deciduous forest. Acta theriol, 17: $315-325$.

56. Zejda J. \& Pelikán J., 1969: Movement and home range of some rodents in bwland forest. Zool. Listy, 18: 143-162.

Acceoted, July 15, 1984.

Henryka CHEŁKOWSKA, Wiera WALKOWA i Krystyna ADAMCZYK

STOSUNKI PRZESTRZENNE W SYMPATRYCZNYCH POPULACJACH GRYZONI: CLE?HRIONOMYS GLAREOLUS, MICROTUS AGRESTIS, APODEMUS AGRARIUS

\section{Streszczenie}

Analizowano rozmieszczenie przestrzenne oraz wzajemne oddziaływania popula:ji trzech gatunków gryzoni: Clethrionomys glareolus, Microtus agrestis i Apocemus agrarius. Badania prowadzono przez 4 lata (X.1977-X.1981) w lasach miessanych na Sląsku $w$ silnie uprzemysłowionym rejonie Polski. Założono trzy jednohektarowe powierzchnie badawcze (A, S, P), które różniły się stopniem degrıdacji zespołów roślinnych i zanieczyszczenia przemysłowego (Tabela 1). Powierchnia A znajdowała się $w$ terenie najbardziej a powierzchnia $P$ w najmniej zdegadowanym.

Gryzonie łowiono w pułapki żywolowne ustawione w sieć $(10 \times 10 \mathrm{~m})$. W ciągu roku przeprowadzono 4 serie połowów (w maju, lipcu, wrześniu i październiku) po 5 dni każda, sprawdzając pułapki rano i wieczorem (łącznie 10 przeglądów w serii. Stosowano metodę CMR (catch, mark, release). Liczebność gryzoni była stosunkowo wysoka (Ryc. 1, 2). 
Analizowano: (1) Charakter rozmieszczenia przestrzennego badanych gatunków (Tabela 5). (2) Zmiany miejsc łowienia się populacji poszczególnych gatunków w obrębie powierzchni badań (Tabela 6). (3) Stałość atrakcyjności punktów połowu dla gryzoni (Ryc. 7, 8). (4) Wielkość i sezonową zmienność areału osobniczego (Ryc. 3, 5). (5) Współwystępowanie poszczególnych par gatunków gryzoni w punktach polowu.

C. glareolus wykazywał największe wartości wyżej wymienionych pierwszych trzech wskaźników. Gatunek ten najostrzej reaguje na zmiany środowiska: wszystkie wskaźniki dla C. glareolus na powierzchni A są mniejsze niż na pozostałych powierzchniach (Tabela 7). Stwierdzono, że wszystkie badane gatunki wykazuja tendencję do wzajemnego unikania się w punktach łowienia (Ryc. 9). Największe wzajemne unikanie się wykazywała para gatunków C. glareolus, M. agrestis. 